\title{
The Impact of CALL on Vocabulary Learning, Speaking Skill, and Foreign Language Speaking Anxiety: The Case Study of Indonesian EFL Learners
}

\author{
Waode Hanafiah $\left(\mathbb{D},{ }^{1}\right.$ Muhammad Aswad $\left(\mathbb{D},{ }^{2}\right.$ Harlinah Sahib $\left(\mathbb{D},{ }^{3}\right.$ Abdul Hakim Yassi ${ }^{D},{ }^{3}$ \\ and Movahede Sadat Mousavi ${ }^{4}{ }^{4}$ \\ ${ }^{1}$ Department of English Education, Universitas Unidayan, Bau-Bau, Indonesia \\ ${ }^{2}$ Department of English Education, Universitas Sulawesi Barat, Majene, Indonesia \\ ${ }^{3}$ Department of Cultural Science, Hasanuddin University, Makassar, Indonesia \\ ${ }^{4}$ Department of Foreign Languages, Allameh Tabataba'i University, Tehran, Iran
}

Correspondence should be addressed to Waode Hanafiah; waodehanafiah190@gmail.com and Movahede Sadat Mousavi; movahede.s@yahoo.com

Received 29 November 2021; Accepted 24 December 2021; Published 21 January 2022

Academic Editor: Ehsan Namaziandost

Copyright $\odot 2022$ Waode Hanafiah et al. This is an open access article distributed under the Creative Commons Attribution License, which permits unrestricted use, distribution, and reproduction in any medium, provided the original work is properly cited.

\begin{abstract}
Using computer-assisted language learning (CALL) in English language learning has not received the attention it deserves in Indonesian EFL context; thus, this study tried to inspect the impacts of CALL on Indonesian EFL learners' vocabulary learning, speaking skill, and speaking anxiety. To reach this end, the Oxford Quick Placement Test (OQPT) was administered to 103 Indonesian EFL students, and 60 of them whose English proficiency levels were intermediate were chosen as the respondents of this investigation. They were divided into two groups: an experimental group and a control group. Then, a vocabulary test, a speaking test, and a Foreign Language Classroom Anxiety Scale (FLCAS) questionnaire were administered to the groups as the pretests of the study. After that, the conversations and the vocabulary items of six lessons of Family and Friends Book 6 were taught to the experimental group by an online instruction (Skype application). On the other side, the same conversations and vocabulary items were taught to the control participants by a conventional instruction (face-to-face class). After teaching the conversations and vocabulary items, the posttests of vocabulary, speaking skill, and anxiety were administered to the groups to determine the influences of the intervention on their vocabulary, speaking, and anxiety. The collected data were analyzed by utilizing independent samples and paired samples $t$-tests, and the gained outcomes indicated that the experimental participants outflanked the control participants both in the speaking and vocabulary posttests. Moreover, the outcomes of the questionnaire demonstrated that the experimental participants had less amount of speaking anxiety compared to the control participants after receiving the treatment. Finally, the implications and the conclusions of the results were explained at the end of the research.
\end{abstract}

\section{Introduction}

Recently, the enormous development of technology and communication has produced a great change not only in communities and globalization but also in educational system. The application of computer and online tools in instructional settings has risen increasingly that had a vital impact on educational improvements. Computer-assisted language learning (CALL) is one of the pivotal means and methods that has an important effect on improving language learning of the students [1]. The usefulness of CALL in learning English language has been examined by several investigations across the globe. Most research outcomes have confirmed the favourable roles of CALL in learning language and language proficiencies. Indeed, this type of technology has boosted language teaching and learning in various EFL contexts, and also it has increased the creativity and the productivity of the students and has contributed to individual learning differences. CALL has been applied for numerous purposes in language learning, including 
language practices, teaching exercises, teaching methods, and even as a useful instrument to cause discussions and language interactions. Nowadays, utilizing computers is appearing as an essential source in language learning and teaching that has got lots of heed in the instructional contexts [2].

CALL is defined as a method of language learning and teaching in which the computers are applied as a tool for presenting, reinforcing, and assessing the materials to be taught, usually encompassing vital interactive elements [3]. CALL provides instructors with a specific instruction allowing people to study and learn at their own paces [4]. According to Tatiana Dina and Ciornei [5], CALL has the potentiality to cause the language interactions among instructors and students. CALL helps to use experimental learning and practice in various fashions, provides helpful feedbacks for students, encourages group and pair work, develops effective and universal learning, boosts students' achievements, paves the way for reaching to the real resources, facilitates effective interactions, individualizes instructions, and motivates the learners [6].

Using CALL can develop EFL learners' speaking skill as a problematic skill for all language students, particularly nonnative EFL students. Speaking is a crucial skill in English language learning, and it is not a simple task and needs much work to produce comprehensible words and utterances. The learners of English language need to improve their ability to speak proficiently, but they face different difficulties while speaking English language. Anxiety is considered as one of the primary difficulties which can prevent learners from speaking well. Speaking anxiety inhibits interactions and communications in language classrooms and consequently negatively influences the learning process [7]. Anxiety can abandon students from the study of language and can affect their speaking performance and proficiency in foreign language [8]. So, it is significant to carry out researches on English language learning in order to improve and develop students' speaking skills and to offer students with facilitating and comfortable environment in the classroom.

Some researchers [9-11] have confirmed the effects of utilizing CALL in promoting vocabulary knowledge. Knowing vocabulary is a primary medium of the four main skills of a language [12]. Vocabulary learning is considered as the first step in learning English as a foreign language. Vocabularies are referred to the words of a language which can be in the forms of single items or phrases that transfer special meanings [13]. We cannot overlook the strength of vocabulary in the students' communications since, without adequate vocabulary, people are not able to comprehend others or transfer their own opinions. Without vocabulary knowledge, the speakers cannot manifest their intentions and purposes [14].

Despite of its importance in language learning, CALL effectiveness has not been examined on vocabulary learning, speaking skill, and foreign language speaking anxiety of Indonesian EFL learners; therefore, this investigation aimed at investigating the impacts of CALL on Indonesian EFL students' vocabulary learning, speaking skill, and anxiety.

\section{Review of the Literature}

2.1. CALL. Today, computers have a vital role in the educational milieu. Prensky [15] stated that, in our time, education without using computer, digital media, or the Internet is pointless for learners. Computers can back learners to personalize instruction as Vahdat and Eidipour [16] prove that computer can assist immensely to the personalization of instruction. Computer helps in the motivation of schoolchildren over personalizing information, using alive things on the screen, and offering exercises which include challenges and curiosity in certain circumstances. Likewise, CALL is a learnercentered method of the education process, meaning that the learners are to control the learning pace and select what must be learned and in what ways they can learn it, which, in turn, causes them feel more confident in learning [16].

CALL is an effective instrument to increase the quality the instruction. This is probably owed to the following points:

(i) Computer can be an appropriate instrument to offer useful classroom activities which help schoolchildren learn skills of the language

(ii) CALL can help learners learn the materials even outside the instructional situations

(iii) CALL can provide individualized, constant, and realistic tasks for the learners

(iv) CALL reduces the indifference of the students and lack of engagement in the process of learning; thus, CALL is a learner-oriented method

(v) CALL can incorporate all language skills

(vi) Computer can offer instant feedbacks [17]

Instructors and scholars have usually cited the advantages of CALL; nonetheless, CALL has its own disadvantages. For example, computers cannot usefully evaluate learners' verbal communications with other students, and what is digitally uttered is totally distinct from that of individuals [18]. In addition, the quality and stability of CALL software are controversial. The mercantile resources that some instructors count on may not educationally produce the desirable outcomes. Furthermore, some instructors and people do not have adequate computer literacy that can hinder the process of learning [18].

Regarding demerits reported above for employing CALL, Al-Kahtani and Al-Haider [19] indicated that instructors evade using technologies in classes for the subsequent reasons:

(i) They have not experienced CALL teaching

(ii) They have not been supported to use technology

(iii) They cannot observe learners during applying technology

(iv) Lack of CALL expert instructors to train computer skills to students

(v) Lack of computer accessibility

(vi) The expensive price of technology tools and the quick changes in technology 
Moreover, Levy [20] reckoned some difficulties in using CALL in the language classroom: (1) "material created by inexperience teachers (software), (2) poor development of natural language processing techniques, (3) poor linguistic modeling, and (4) false starts and inadequate realizations of CALL. Computer's limit ability in handling natural language" (p. 2).

All things considered, CALL has both merits and demerits, but its merits are more. CALL can ease language teaching and learning, and using computers can have favorable effects on developing learners' attainment [21]. The studies come to realize that the use of CALL does not eliminate the roles of the teachers since teachers can help people focus on the main objectives of communication and language learning [17]. Consequently, instructors should not be neglected or substituted by the computers.

2.2. Anxiety. CALL can have a constructive effect on affective factors involved in language learning. The affective filter hypothesis was first presented by Dulay and Burt [22] and was integrated by Krashen as one of his five input hypotheses in 1985. Krashen [23] stated that students learn L2 just when they receive comprehensible input, and if their anxiety is very low, they will learn language successfully. Based on Krashen, anxiety is one of the main affective filters. Gardner and MacIntyre [24] described language anxiety as an annoying worry encountered when a situation wants the student to apply L2 in which he or she is not completely knowledgeable. Anxiety is a displeasing feeling that dominates the excitement of the learners and finally makes worry about attaining his or her desires. When the feeling of anxiety improves in a specific situation, the feeling of fear happens within a student [25]. Anxious students have a high affective filter that hinders learning achievement to take place.

Anxiety is defined by Horwitz, Horwitz, and Cope [26] as the subjective feelings of tensions, apprehensions, and worries related to an arousal of the autonomic nervous system. As shown in this definition, anxiety has some main qualities such as worry, uneasiness, fear, and undesirable conditions that can impede the abilities and performance of learners in different settings. Anxiety is a psychological agent supposed to be useful in evaluating the level of success in learning language process [27]. Young [28] explains anxiety in FL classes as a complex process that cannot be simply determined, but which certainly influences second language learning at different levels.

2.3. Speaking Skill. Speaking is one of the four macrolanguage skills that must be improved in English for Foreign Language Learners (EFL) especially in nonnative countries where people do not have access to feedbacks and real context [29]. According to the importance of speaking and the purpose of communicating in English, many linguists and experts believe that speaking is one of the vital skills for each language learner in every stage of education, for instance in schools, language institutes, or even at the university level, specifically for applied linguistics students
$[30,31]$. Although speaking by the means of communication is necessary for everyone, applied linguistic students should focus more on the speaking skills because they should represent the accurate and fluent way of speaking among nonnative learners.

Parmawati [32] indicated that speaking is the most significant skill of the English language since speaking is a communicative means in our routine life. Furthermore, Sartika [33] declared that speaking is the skill that the learners will be assessed upon most in real circumstances. It is a skill that is mainly utilized in communications. In evolving speaking skill, learners not only have to acquire and master vocabularies, pronunciations, grammar, and other English skills but also need to shape their confidence, public speaking, and their speaking fluency [34].

Speaking is an oral process to express thoughts and emotions, to ponder on experiences, and to share facts. Ideas are the core of what we are speaking about and words are tools to express them. Speaking is a sophisticated task as it encompasses the capability of thought process, discussions, and social abilities [35]. Based on Hornby, Wehmeier, and Ashby [36]; speaking is talking to someone about something, to have a dialog with a person.

2.4. Vocabulary Learning. CALL can be used to teach English vocabulary more efficiently to EFL learners. Vocabulary has a significant role in second language achievement and academic attainment. This role has long been ignored [37]. Nevertheless, vocabulary has recently gained high attention in the language learning curriculum. This is because of some reasons, including the effect of comprehensionbased methods in language improvement, the research effort in applied linguistics, and the enhancement of computerbased language corpus [38].

Some academics regard vocabulary understanding as the most significant agent in schooling accomplishment for the students of a foreign or a second language. They show that vocabulary understanding is highly associated with reading comprehension, and also it results in more achievements at schools [39]. Vocabulary is a central part of language competence and how well a person speaks, listens, reads, and writes is relied upon vocabulary knowledge [40]. Based on Richards and Renandya [40]; without learning adequate vocabularies and approaches for mastering new vocabulary items, learners usually cannot develop their language learning. Vocabulary acquisition has usually been a common topic in CALL instruction for forty years. In the arena of learning foreign language, constant computer-assisted vocabulary instruction (CAVI) instructions have been created to ease the intricate process of L2 vocabulary acquisition. CAVI is regarded an attractive application of CALL which involves practices relating to using the computer for vocabulary learning and education objectives. Vocabulary learning/teaching is a greatly prevalent topic in CALL applications since the early stages of CALL [41].

Lack of vocabulary knowledge can restrict students' comprehension and communication. Incorrect vocabulary use can cause a significant consequence for communications 
because the vocabulary items carry the speakers' or writers' intended and meaningful messages [42]. There are several restrictions or problems encountered by instructors and students in applying different vocabularies [43, 44]. Many problematic challenges are related to the limited time and opportunities to both learn and teach vocabulary. EFL instructors do not have enough time to instruct all the vocabularies which are needed for the students. Vocabulary learning is one of the boring learning activities which the language students encounter. Vocabulary is hard for the sake of two significant reasons: one reason is that there are numerous words to be learned, and the other reason is that not sufficient attention has been paid to the learners' challenges and difficulties in this regard [42]. Therefore, teachers and researchers should use different and attractive methods to teach vocabulary to the EFL learners.

2.5. Related Studies. Several experimental studies were carried out to inspect the effect of CALL on diverse skills and subskills of English language. Pahlavanpoorfard and Soori [45] did an empirical study to examine the effect of utilizing computers on word mastering of Iranian EFL learners. They selected 40 male and female participants on the basis of the OQPT. Then, they divided them into an experimental group and a control group. The experimental participants were trained by two unlike methods such as software-based and game-based methods. The control participants received a traditional instruction. The outcomes of the research indicated that those students who had used the computer outflanked those students who had used a traditional method. The results also demonstrated that using computer assisted the students to learn more vocabularies after the treatment.

Ghanbari, Shamsoddini, and Radmehr [37] intended to investigate the impacts of a computerized program on boosting words and reading skill of Iranian EFL students. To do so, the researchers selected 60 first-grade high school students in Bushehr, Iran. Then, the subjects were divided into two groups, and every group included 30 participants. The study findings depicted that the computerized programs were helpful in vocabulary developing and reading comprehension skill for the experimental participants. Based on these outcomes, the researchers commented that EFL Iranian instructors need to utilize CALL as an instrument particularly for improving learners' lexis and reading skills and learning the language generally.

Mousavi and Nemati [46] carried out a research to explore the effects of applying vocabulary software on Iranian EFL students' vocabulary knowledge. Fifty-four EFL students including both girls and boys took part in the investigation. The respondents were assigned to two groups. After that, the groups were administered a researcher-made vocabulary pretest. The control respondents were trained the words in the typical way of a printed textbook, while the experimental respondents were trained by the software version of the same coursebook. The results showed that though both approaches had favourable effects on participants' word learning, applying the software was more helpful than utilizing the printed textbook.
Zarei and Asadi Amani [47] examined the impacts of different online strategies (word reference, media, and vocabulary games) on reading skills as well as vocabulary learning. For doing this study, 60 language students were chosen and assigned to three groups, and every group was randomly divided into one of the intervention situations. After selecting the participants, they were administered a vocabulary test which was given as the pretest of the study. Within the treatment, the students in those three groups were instructed via the online vocabulary games, online media with transcripts, and online word references. After the treatment, a reading comprehension posttest, a vocabulary posttest, and a vocabulary production posttest were given to the groups to measure the treatment effects. The finding revealed that the online media participants outflanked the other participants. According to the results, it can be inferred that various online instruments may have pivotal impacts on mastering diverse aspects of language. This indicates that using only one online tool may not essentially bring about favourable outcomes.

Alahmadi [2] investigated the effects of CALL on grammar achievement for English as a foreign language (EFL) in a Saudi setting. The respondents of this investigation were 150 female students from a preparatory year who study English language as their foreign language. The grammar points were instructed to the control participants via a printed form from the textbook. The experimental participants received the grammar points via employing an online learning management system. The findings of the posttest supported the hypothesis of this research so that there was a considerable difference in the findings between the control and the experimental participants in the level of grammar learning for the grammatical rule and form.

Enayati and Pourhosein Gilakjani [13] inspected the effects of CALL on Iranian intermediate students' vocabulary knowledge. The researchers selected one experimental group and one control group to do the research. The TEM software was applied to train vocabulary items to the experimental subjects, and the control subjects received a conventional instruction. The gained outcomes showed that the experimental respondents outflanked the control respondents and they held a positive attitude toward CALL.

Mahmoudi [48] studied the influences of online instruction through smartphones on Iranian EFL students' grammatical accuracy development. To reach this objective, the researcher utilized the experimental approaches and selected two groups of the upper-intermediate learners: one experimental group and one control group. The conventional instruction was applied in teaching grammar to the control participants, while the online instruction was utilized to teach the experimental participants. The results indicated that there were remarkable differences between the experimental and the conventional participants, and the experimental participants who used online instruction had better performances.

Çakmak, Namaziandost, and Kumar [49] aimed to examine the effects of using a CALL-enhanced L2 vocabulary learning program on EFL learners' vocabulary enhancement. Seventy-six preintermediate EFL students took part in this research and were assigned to two groups: the experimental 
group and the control group. During the treatment, the experimental group was required to use a computer-enhanced flashcard software program on their laptops, mobile phones, or other mobile tools at their discretion. The control participants were taught by using a conventional method. The outcomes revealed that the experimental participants outflanked the control participants in the posttest of vocabulary.

Recently, Hashemifardnia, Shafiee, Rahimi Esfahani, and Sepehri [1] examined the impacts of Massive Open Online Course (MOOC) on Iranian EFL students' speaking complexity, accuracy, and fluency (CAF). To do this study, the researchers gave the OQPT to 130 Iranian EFL students and selected 60 intermediate participants. Then, the participants were divided into an experimental group $(n=30)$ and a control group $(n=30)$. The experimental participants received the online-delivered treatment by utilizing Skype. On the other side, the control participants did not receive an Internet-delivered instruction, and they were trained traditionally via a face-to-face instruction. The findings of the one-way ANCOVA test showed that there were noticeable differences between the posttests of the experimental and the control participants. The results indicated that the experimental participants considerably outperformed the control group $(p<0.05)$ on the posttest. Moreover, the outcomes of the onesample $t$-test depicted that the participants held a significantly desirable attitude toward applying MOOC education.

Based on the literature review, speaking is the main language skill; however, most people in EFL settings struggle to overcome their speaking problems because their exposures to contexts where speaking skill can be practiced is rare $[50,51]$. According to the reviewed literature, vocabulary learning in a foreign language is a difficult and time-consuming task. Therefore, utilizing a proper approach for teaching and learning vocabulary is crucially needed. Technology applications, especially CALL has lately activated some scholars to investigate the influences of CALL on vocabulary learning of EFL students. In the same vain, this study examined the effects of CALL on Indonesian EFL learners' vocabulary learning, speaking skill, and anxiety. Accordingly, the following questions were posed in this research:

(i) RQ1: does using CALL affect Indonesian EFL learners' vocabulary learning positively?

(ii) RQ2: does using CALL affect Indonesian EFL learners' speaking skill positively?

(iii) RQ3: does using CALL affect Indonesian EFL learners' foreign language speaking anxiety positively?

Based on the above-stated questions, the following null hypotheses were suggested:

(i) HO1: using CALL does not affect Indonesian EFL learners' vocabulary learning positively

(ii) HO2: using CALL does not affect Indonesian EFL learners' speaking skill positively

(iii) HO3: using CALL does not affect Indonesian EFL learners' foreign language speaking anxiety positively

\section{Method}

3.1. Design of the Study. This study used a quasi-experimental study with a quantitative method in the data collection procedure. The design of this research was based on a quasi-experimental method (pretest treatment posttest). This research had one control group and one experimental group, and it had the variable of CALL as the independent variable and vocabulary learning, speaking skill, and speaking anxiety as the dependent variables.

3.2. Participants. For performing this investigation, 60 Indonesian intermediate EFL students were chosen from 103 people at an English Language Institution in Indonesia. The participants' age was between 20 and 33, and their gender was male. The participants have studied English as a foreign language since 2014. The English language proficiency levels of the participants were assessed by giving the Oxford Quick Placement Test (OQPT). The convenience sampling method was employed to choose the respondents since the researchers had easy access to them. The respondents were randomly divided into two groups (experimental and control), and there were 30 participants in each group.

3.3. Instruments. The first instrument applied in the current research to homogenize the subjects was a proficiency test; Oxford Quick Placement Test (OQPT). It was given to 103 learners to assess their English language proficiencies, and according to it, those students whose scores were between 30 and 47 (out of 60) were regarded as the intermediate learners and were chosen as the target respondents of the control and the experimental groups.

The second tool for collecting the needed data was a teacher-designed vocabulary pretest that was created based on the participants' textbook. This test included 20 objective items. The reliability and the validity of the pretest were tested. After making the test, it was examined by three English instructors for its face and content validity. In fact, three English instructors read through the test and proposed some modifications concerning the clarity, simplicity, and the representativeness. After that, the pretest was modified and then piloted on the similar participants in another institute whose textbook and English levels were similar to the target participants. Eventually, the pretest was ready to administer to the respondents. Its reliability was measured by using the KR-21 formula $(r=0.79)$.

The third tool that was applied in the current research was a researcher-designed vocabulary posttest-the modified version of the pretest. It was given to assess the effect of the treatment on the students' vocabulary knowledge. All features of the posttest were identical to the pretest. The only difference was that the order of the items and the options was changed to remove the potential recall of the pretest answers. The posttest was considered both reliable and valid because it was the modified version of the pretest.

The fourth tool utilized in this study was a questionnaire, Foreign Language Classroom Anxiety Scale (FLCAS), made 
by Horwitz, Horwitz, and Cope [26], was applied as the anxiety pretest of this study. There were 33 items in this fivepoint Likert scale test. The validity of the FLCAS was verified by a group of English professors, and its reliability was computed by Cronbach Alpha $(r=.86)$. It should be noted that the FLCAS questionnaire was utilized twice in this investigation; once as the pretest and once as the posttest.

The fifth tool that was employed in this research was a researcher-designed speaking pretest. The pretest contained some items from the participants' course book. The subjects were required to speak about the subjects of the units about 2 to 3 minutes, and their speeches were recorded for the second-rater. The reliability of the speaking pretest was confirmed by the conduct of the inter-rater reliability $(r=.83)$.

The sixth instrument was the speaking posttest. The topics of this test were selected from their course book. The difficulty levels of the topics were the same in the speaking pre- and posttests. The posttest reliability was calculated by using inter-rater reliability through using Pearson correlation analysis $(r=.78)$. The validity of the pre- and posttests was confirmed by three experienced English professors. Three English professors checked the topics of the speaking pre- and posttests and proposed some modifications concerning the clarity and simplicity of the topics. After that, two of the topics were changed and were rechecked by the professors. Finally, they verified that the selected topics are suitable for the speaking tests.

The researchers used the speaking checklist of Hughes as the seventh instrument. They applied this checklist in order to score the students' speeches. The raters gave scores to the students' speeches according to the mentioned checklist.

3.4. Procedure. In the first step, the OQPT was given to 103 Indonesian EFL students, and based on their performance in this test, 60 intermediate participants were chosen for the target population of the research. After choosing the target respondents, they were randomly assigned to two groups: experimental and control. After that, all the respondents were pretested by a vocabulary test, a speaking test, and an anxiety test, and then the treatment was started. Regarding the treatment, the conversations and vocabularies of six lessons from Family and Friends Book 6 were instructed to the respondents of the experimental group by using a CALL-based instruction. In fact, in each online session, one conversation and new words were sent to the experimental group via Skype application. The audio file of the conversation, the meanings, synonyms, and pronunciations of the vocabularies were sent to the learners, and they were required to practice them. On the other side, the participants of the control group were deprived of the Internet and the Skype application, and they received a traditional conversation and vocabulary instruction. Indeed, the researcher held a face-to-face class for the control group and attended the class personally and began teaching the conversations and the vocabularies to this group. The researcher provided synonyms and meanings for the words and pronounced the new words for the participants. Also, he played the audio files of the conversations and required the students to practice each conversation in pairs. After teaching all words and conversations, the posttests of vocabulary, speaking skill, and anxiety were given to the participants to measure the impact of the instruction on their vocabulary, speaking, and anxiety.

The treatment lasted 17 sessions; the allocated time for each session was 60 minutes. In the first session, the participants were homogenized; in sessions two to four, the pretests of vocabulary, speaking skill, and speaking anxiety were administered. In ten sessions, the treatment was practiced (teaching conversations and vocabularies through Skype). In the last three sessions, the posttests of vocabulary, speaking skill, and speaking anxiety were administered.

3.5. Data Analysis. The collected data were analyzed by applying SPSS software, version 22. Firstly, descriptive statistics were calculated. Secondly, independent samples and paired sample $t$-tests were utilized to determine the effects of the treatment on the students' vocabulary knowledge, speaking skill, and anxiety. The independent samples $t$-test was applied for comparing the performances of the control group with the experimental group both in the pretest and the posttests. The paired sample $t$-test was run to measure if the mean differences between two sets of observations were zero.

\section{Results}

Firstly, the Kolmogorov-Smirnov (K-S) test was utilized to inspect the quality of data normality before conducting any data analysis. The obtained results depicted that the distribution of the data was normal because the sig. values were higher than 0.05 . Therefore, the researchers used paired samples and independent sample $t$-tests to gain the final findings.

4.1. Effects of CALL on EFL Learners' Anxiety. To prove if CALL had effects on Indonesian EFL students' anxiety or not, the FLCAS questionnaire was utilized once as the pretest and once as the posttest, and its collected data are analyzed in the following tables.

As data analysis in Table 1 shows, the mean score of the experimental group is 70.56 and the mean score of the control group is 72.13 in the pretest of anxiety. It appears that both groups had nearly similar anxiety scores prior to the instruction.

According to the outcomes in the above table (Table 2), sig. (0.50) is greater than 0.05; consequently, we can say that both experimental and control groups got the same anxiety scores before receiving the instruction. In other words, the participants of this study had the same level of speaking anxiety before receiving the treatment.

As depicted in Table 3, the mean score of the control group is 75.23, and the mean score of the experimental group is 112.60 in the posttest of anxiety. We can strongly claim that the experimental participants gained higher marks in the posttest of anxiety.

According to the outcomes of independent samples $t$ test displayed in Table 4, we can come to the conclusion that the experimental participants outflanked the control 
TABle 1: Descriptive statistics of the experimental and control groups in the anxiety pretests.

\begin{tabular}{lcccc}
\hline & \multicolumn{3}{c}{ Group statistics } & \\
Groups & $\mathrm{N}$ & Means & Std. deviations & Std. error means \\
\hline Control & 30 & 72.13 & 11.61 & 2.12 \\
Experimental & 30 & 70.56 & 4.97 & .90 \\
\hline
\end{tabular}

TABLE 2: Inferential statistics of the experimental and control groups in the anxiety pretest.

Levene's test for equality of variances $t$-test for equality of means

\begin{tabular}{|c|c|c|c|c|c|c|c|c|c|}
\hline \multirow[t]{2}{*}{$\mathrm{F}$} & & \multirow[t]{2}{*}{ Sig. } & \multirow[t]{2}{*}{$\mathrm{t}$} & \multirow[t]{2}{*}{ Df } & \multirow[t]{2}{*}{ Sig. (2-Tailed) } & \multirow[t]{2}{*}{ Mean difference } & \multirow[t]{2}{*}{ Std. error difference } & \multicolumn{2}{|c|}{$\begin{array}{l}95 \% \text { confidence } \\
\text { interval of the } \\
\text { difference }\end{array}$} \\
\hline & & & & & & & & Lower & Upper \\
\hline Equal variances assumed & 0.62 & 0.43 & 0.66 & 58 & 0.50 & 1.53 & 2.30 & -3.08 & 6.15 \\
\hline Equal variances not assumed & & & 0.66 & 39.29 & 0.50 & 1.53 & 2.30 & -3.13 & 6.19 \\
\hline
\end{tabular}

TABle 3: Descriptive statistics of the experimental and control groups in the anxiety posttests.

\begin{tabular}{lccccc}
\hline & Groups & N & Means & Std. deviations & Std. error mean \\
\hline \multirow{2}{*}{ Scores } & Control & 30 & 75.23 & 17.91 & 3.27 \\
& Experimental & 30 & 112.60 & 43.75 & 7.98 \\
\hline
\end{tabular}

participants in the anxiety posttest because sig. (0.00) is less than 0.05 . This table shows that there are significant differences between the anxiety posttests of both groups in favour of the experimental group.

Table 5 displays that the differences between the anxiety pretest and posttest of the control group were not remarkably significant since sig. (0.32) is higher than 0.05 . Based on the findings of this table, the differences between the anxiety pretest and posttest of the experimental participants were remarkable since sig. $(0.00)$ is smaller than 0.05 . Based on the results, we can conclude that the treatment (CALL instruction) had positive impacts on Indonesian EFL learners' speaking anxiety, implying that the CALL instruction reduced their speaking anxiety.

\subsection{Effects of CALL on EFL Learners' Vocabulary Knowledge.} A vocabulary pretest and a posttest were administered to the respondents to examine the influences of CALL on their vocabulary development. The obtained data are analyzed in the following tables.

Table 6 indicates that the mean score of the control group is 12.56 , and the mean score of the experimental group is 13.30 in the pretest of vocabulary. To see the differences between the vocabulary pretest and posttest, an independent samples $t$-test was run in the following table.

An independent samples $t$-tests was run in Table 7 to find out if the differences between the vocabulary pretest and posttest of the participants were considerable or not. Based on the results, Sig. is 0.24 which is higher than 0.05 , so there were not a noticeable difference between the respondents' vocabulary pretest and posttest.

Table 8 indicates that the means of the control participants and the experimental participants are 14.36 and 17.13, respectively. It appears that the experimental participants outflanked the control participants in the vocabulary posttest. We conducted an independent samples $t$-test in the following table to discover whether the differences between the vocabulary posttests of the groups were remarkable or not.

As Table 9 depicts, the sig. (0.00) of the vocabulary posttest is less than 0.05 ; therefore, it can be said that the experimental participants did considerably better than the control participants in the vocabulary posttest. According to the outcomes, we can say that the CALL instruction helped Indonesian EFL learners develop their vocabulary learning.

As shown in Table 10, sig. (.08) of the control group is higher than 0.05 ; therefore, the differences between the speaking pretest and posttest of this group were considerable. On the other side, the differences between the speaking pretest and posttest of the experimental participants were remarkably considerable since sig. (0.00) is less than 0.05. Accordingly, we can conclude that using CALL assisted Indonesian EFL students to enhance their knowledge of vocabulary.

4.3. Effects of CALL on EFL Learners' Speaking Skill. To assess the impacts of CALL on Indonesian EFL learners' speaking skill, a pretest and a posttest of speaking were given to the respondents, and their collected data are analyzed in the following tables.

The descriptive statistics (e.g., means and standard deviations) of the control and the experimental groups are presented in the above table (Table 11). The control participants' mean score is 14.30 , and the experimental participants' mean score is 14.16. It seems that both groups have nearly similar mean scores in the speaking pretest.

To understand if there were any remarkable differences between the speaking pre-tests of both groups, an independent samples $t$-test was applied in Table 12. Since sig. (0.76) is greater than 0.05 , we can say that there were no significant differences between the speaking pretests of the control and the experimental groups. 
TABLE 4: Inferential statistics of the experimental and control groups in the anxiety posttests.

\begin{tabular}{|c|c|c|c|c|c|c|c|c|c|}
\hline \multicolumn{5}{|c|}{ Levene's test for equality of variances } & \multicolumn{3}{|c|}{$t$-test for equality of means } & & \\
\hline \multirow[t]{2}{*}{$\mathrm{F}$} & & \multirow[t]{2}{*}{ Sig. } & \multirow[t]{2}{*}{$\mathrm{t}$} & \multirow[t]{2}{*}{ Df } & \multirow[t]{2}{*}{ Sig. (2-Tailed) } & \multirow[t]{2}{*}{ Mean difference } & \multirow[t]{2}{*}{ Std. error difference } & \multicolumn{2}{|c|}{$\begin{array}{l}95 \% \text { confidence } \\
\text { interval of the } \\
\text { difference }\end{array}$} \\
\hline & & & & & & & & Lower & Upper \\
\hline Equal variances assumed & 102.55 & 0.00 & 4.32 & 58 & 0.00 & 37.36 & 8.63 & 54.64 & 20.08 \\
\hline Equal variances not assumed & & & 4.32 & 38.45 & 0.00 & -37.36 & 8.63 & 54.83 & 19.89 \\
\hline
\end{tabular}

TABLE 5: Paired samples statistics of the experimental and control groups in the anxiety pre and posttests.

\begin{tabular}{|c|c|c|c|c|c|c|c|c|c|}
\hline \multicolumn{10}{|c|}{ Paired differences } \\
\hline & & \multirow[t]{2}{*}{ Mean } & \multirow[t]{2}{*}{ Std. deviations } & \multirow[t]{2}{*}{ Std. error means } & \multicolumn{2}{|c|}{$\begin{array}{l}95 \% \text { confidence } \\
\text { interval of the } \\
\text { differences }\end{array}$} & \multirow[t]{2}{*}{$t$} & \multirow[t]{2}{*}{ Df } & \multirow[t]{2}{*}{ Sig. (2-Tailed) } \\
\hline & & & & & Lower & Upper & & & \\
\hline Pair 1 & Conpre-conpost & 1.56 & 8.58 & 1.56 & -4.77 & 1.63 & 1.00 & 29 & 0.32 \\
\hline Pair 2 & Expre-expost & 72.96 & 15.56 & 2.84 & -78.77 & -67.15 & 25.67 & 29 & 0.00 \\
\hline
\end{tabular}

TABLE 6: Descriptive statistics of the experimental and control groups in the vocabulary preest.

\begin{tabular}{lcccc}
\hline Groups & $N$ & Means & Std. deviations & Std. error means \\
\hline Control & 30 & 12.56 & 2.09 & 0.38 \\
Experimental & 30 & 13.30 & 2.68 & 0.48 \\
\hline
\end{tabular}

TABLE 7: Inferential statistics of the experimental and control groups in the vocabulary pretest.

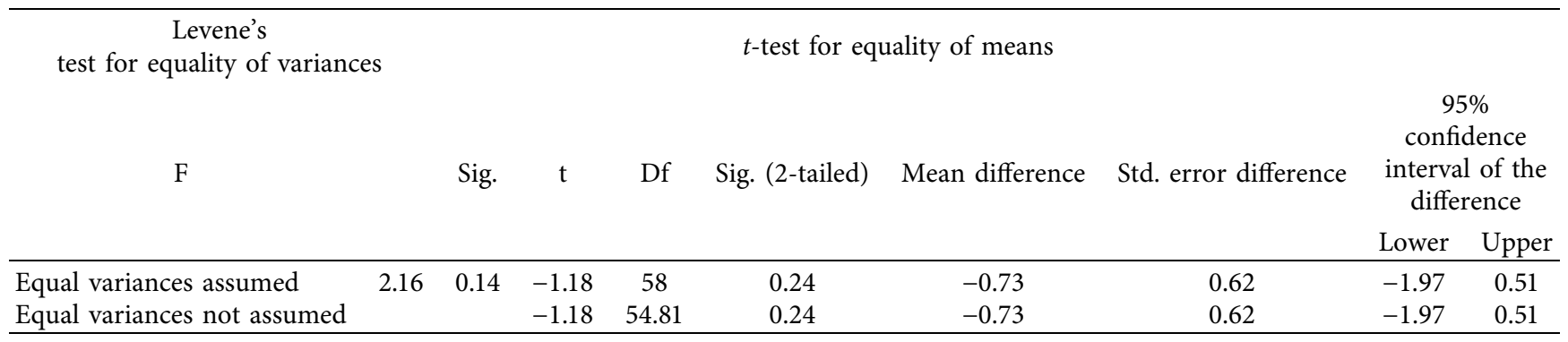

TABLE 8: Descriptive statistics of the experimental and control groups in the vocabulary posttests.

\begin{tabular}{lcccc}
\hline Groups & $N$ & Means & Std. deviations & Std. error means \\
\hline Control & 30 & 14.36 & 3.16 & 0.57 \\
Experimental & 30 & 17.13 & 2.44 & 0.44 \\
\hline
\end{tabular}

TABLE 9: Inferential statistics of the experimental and control groups in the vocabulary post-tests.

\begin{tabular}{|c|c|c|c|c|c|c|c|c|c|}
\hline \multicolumn{5}{|c|}{ Levene's test for equality of variances } & \multicolumn{3}{|c|}{$t$-test for equality of means } & & \\
\hline \multirow[t]{2}{*}{$\mathrm{F}$} & & \multirow[t]{2}{*}{ Sig. } & \multirow[t]{2}{*}{$t$} & \multirow[t]{2}{*}{ Df } & \multirow[t]{2}{*}{ Sig. (2-tailed) } & \multirow[t]{2}{*}{ Mean difference } & \multirow[t]{2}{*}{ Std. error difference } & \multicolumn{2}{|c|}{$\begin{array}{l}95 \% \text { confidence } \\
\text { interval of the } \\
\text { difference }\end{array}$} \\
\hline & & & & & & & & Lower & Upper \\
\hline Equal variances assumed & 1.97 & 0.16 & 3.78 & 58 & 0.00 & -2.76 & 0.730 & -4.22 & -1.30 \\
\hline Equal variances not assumed & & & 3.78 & 54.51 & 0.00 & -2.76 & 0.73 & -4.23 & -1.30 \\
\hline
\end{tabular}


TABLE 10: Paired samples statistics of the experimental and control groups in the vocabulary pre- and posttests.

\begin{tabular}{|c|c|c|c|c|c|c|c|c|c|}
\hline \multicolumn{10}{|c|}{ Paired differences } \\
\hline & & \multirow[t]{2}{*}{ Mean } & \multirow[t]{2}{*}{ Std. deviation } & \multirow[t]{2}{*}{ Std. error mean } & \multicolumn{2}{|c|}{$\begin{array}{l}95 \% \text { confidence } \\
\text { interval of the } \\
\text { difference }\end{array}$} & \multirow[t]{2}{*}{$\mathrm{t}$} & \multirow[t]{2}{*}{ Df } & \multirow[t]{2}{*}{ Sig. (2-tailed) } \\
\hline & & & & & Lower & Upper & & & \\
\hline Pair 1 & Conpre-compost & -0.73 & 2.24 & 0.40 & -1.57 & 0.10 & 1.79 & 29 & 0.08 \\
\hline Pair 2 & Expre-expost & -4.13 & 3.74 & 0.68 & -5.53 & -2.73 & 6.04 & 29 & 0.00 \\
\hline
\end{tabular}

TABle 11: Descriptive statistics of the experimental and control groups in the speaking pre-tests.

\begin{tabular}{llccc}
\hline Groups & $N$ & Mean & Std. deviation & Std. error mean \\
\hline Control & 30 & 14.30 & 1.68 & .30 \\
Experimental & 30 & 14.16 & 1.78 & .32 \\
\hline
\end{tabular}

TABLE 12: Inferential statistics of the experimental and control groups in the speaking pretests.

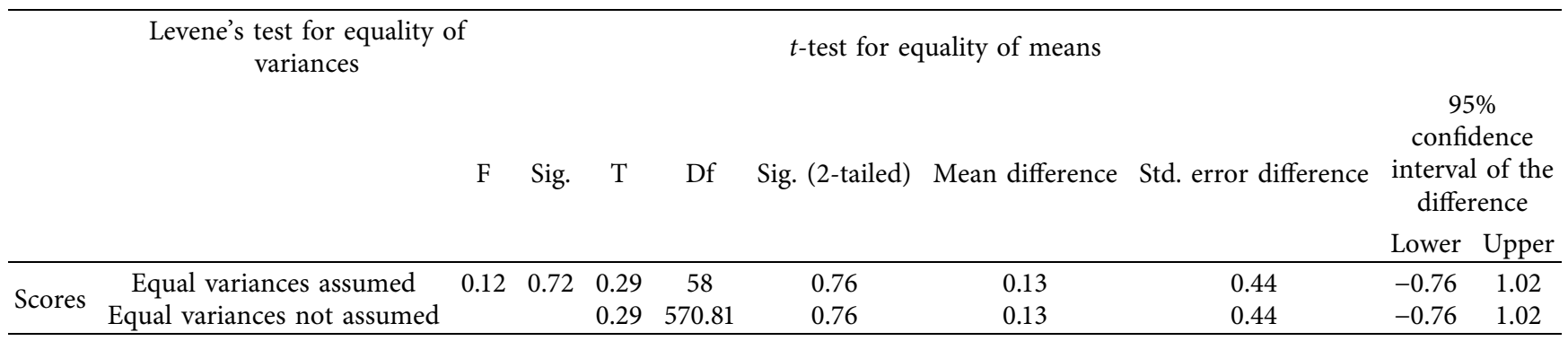

In Table 13, the descriptive statistics of the speaking posttests of the control and the experimental are depicted. The mean scores of the control and the experimental groups are 15.13 and 18.43, respectively. According to this table, we can say that the experimental participants outflanked the control participants in the speaking posttest.

An independent samples $t$-test was run in Table 14 to find out if there were any noticeable differences between the speaking posttests of both groups. Since sig. (0.00) is smaller than 0.05 , it can be said that there were significant differences between the speaking posttests of both groups in favour of the experimental group.

The researchers applied a paired samples $t$-test in $\mathrm{Ta}$ ble 15 for comparing the speaking pretest and the posttest of the control group. The results of this test indicate that sig. (0.11) is higher than 0.05 ; consequently, we can say that the differences between the speaking pre- and posttests of the control group were not considerable. The results of the second paired samples $t$-test reveal that sig. $(0.00)$ is less than 0.05 ; therefore, it can be claimed that there was a remarkable difference between the speaking pretest and the posttest of the experimental participants.

\section{Discussion of the Study}

To answer the questions of the research, the researchers used paired samples $t$-test and independent samples $t$-test. The results showed that the experimental students who received the instruction through CALL had better performances in their vocabulary and speaking posttests compared to the control group. The outcomes statistically indicated that the experimental participants outflanked the control participants in the anxiety posttest. Therefore, the research null hypotheses are all rejected.

The outcomes of this study are supported by Mahmoudi [48] who investigated the effects of online instruction by using smartphones on EFL students' grammatical accuracy development. The outcomes showed that there was a considerable difference between the experimental and the control participants and online instruction developed the grammar knowledge of the experimental group. Furthermore, the outcomes of this research confirm the findings of Zarei and Asadi Amani [47] who inspected the impacts of different online strategies (word reference, media, and vocabulary games) on reading skill and vocabulary knowledge of EFL learners. The outcomes of their research depicted that the online groups outflanked the conventional groups after the intervention.

The findings of this investigation are in agreement with Alipour who inspected the impacts of online and blended instructions on enhancing vocabulary learning among Iranian intermediate EFL students. The results indicated both online and blended learning groups outflanked the control group. Besides, the findings of our research are advocated by Alahmadi [2] who surveyed the impact of CALL on grammar acquisition of Saudi EFL students and concluded that the empirical group substantially outperformed the control group in the grammar posttest. 
TABLE 13: Descriptive statistics of the experimental and control groups in the speaking posttests.

\begin{tabular}{lcccc}
\hline Groups & $N$ & Means & Std. deviations & Std. error means \\
\hline Control & 30 & 15.13 & 2.08 & .37 \\
Experimental & 30 & 18.43 & 1.71 & .31 \\
\hline
\end{tabular}

TABLE 14: Inferential statistics of the experimental and control groups in the speaking posttests.

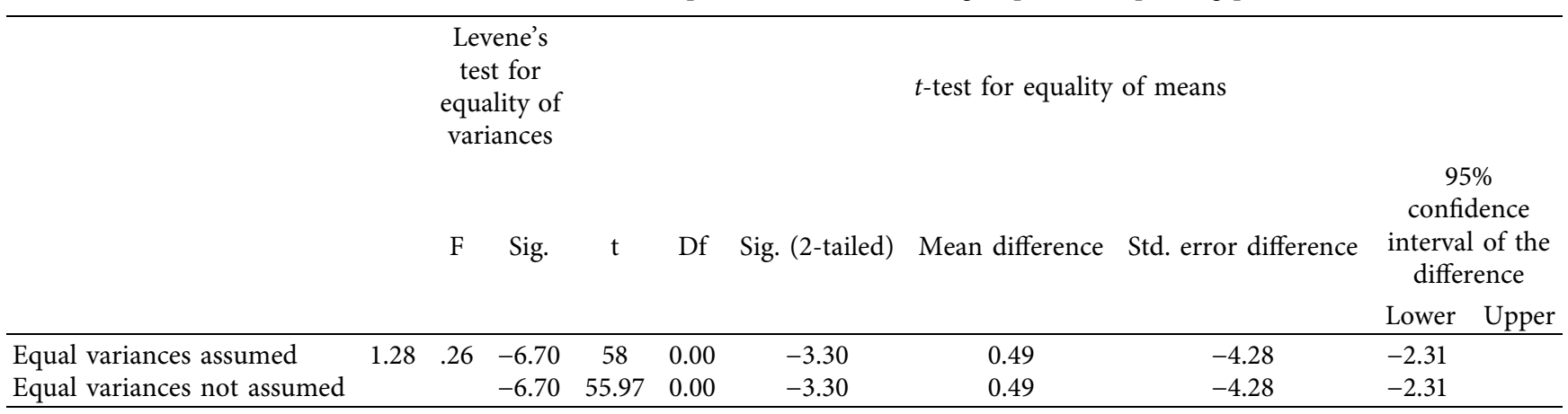

TABle 15: Paired samples statistics of the experimental and control groups in the speaking pre- and posttests.

\begin{tabular}{|c|c|c|c|c|c|c|c|c|c|}
\hline & & & & red differences & & & & & \\
\hline & & Mean & Std. deviation & Std. error mean & $\begin{array}{r}95 \% \\
\text { inter } \\
\text { dif }\end{array}$ & $\begin{array}{l}\text { idence } \\
\text { of the } \\
\text { nce }\end{array}$ & $t$ & Df & Sig. (2-tailed) \\
\hline & & & & & Lower & Upper & & & \\
\hline Pair 1 & Conpre-conpost & -.83 & 1.28 & 0.23 & -1.31 & -.35 & 3.54 & 29 & 0.11 \\
\hline Pair 2 & Expre-expost & -4.26 & 2.50 & 0.45 & -5.20 & -3.33 & 9.33 & 29 & 0.00 \\
\hline
\end{tabular}

The findings of the present research are in agreement with Çakmak et al. [49], who investigated the effect of using a CALL-enhanced L2 vocabulary learning software program on the L2 vocabulary enhancement of students. Their findings depicted that the experimental group had better performances than the control group in the vocabulary posttest. Furthermore, our results are congruent with Enayati and Pourhosein Gilakjani [13] who inspected the effects of CALL on Iranian intermediate students' vocabulary knowledge. Their outcomes of the investigation depicted that the respondents of the experimental group outflanked the control group, and they presented a positive attitude toward CALL.

The outcomes of the current investigation are supported by Harasim's [52] online collaborative learning theory that confirmed the advantages of applying the Internet and online instruction in the teaching and learning process. Based on this theory, learners can solve their difficulties cooperatively, and this cooperation can result in English learning improvement. Also, our findings are advocated by connectivism theory proposed by Siemens [53] asserting that students learn when they use online instruction and connect with their pairs and classmates.

The development of Indonesian EFL students in the posttests of vocabulary, speaking, and anxiety can be as a result of online instruction since online learning can be attractive for EFL learners. As Gilbert [54] stated, online instruction is appealing to many students and is getting more commonplace in situations from elementary schools to high schools and into postsecondary educations. Online instruction is attractive and effective for different groups of the students where conventional instructions are deficient or incapable to meet their needs. The demand for online instruction is stemmed from a push "to provide quality education to all students, regardless of location and time" (Chaney [55], p. 21).

Online instruction is a student-centered teaching method which can use online tools and resources to share information outside of the class regardless of constraints of time and place among learners. This method mixes selfstudy with asynchronous interaction to improve learning, and it can be applied to facilitate learning in conventional on-campus educations, distance educations, and continuing educations. Online instruction permits learners to have more freedom to perform their learning process without the time and space limitations (Ge, [56]). The use of online education can be attractive for the people, it can involve them in learning outside of the class context, it can foster the cooperative learning among the students, it can encourage self-study among the people, and it can boost the selfconfidence of the students. The benefits mentioned for the online instruction can be the reasons why the experimental participants gained better scores in their posttests comparing to the control participants. In other words, the advantages reported for the online instruction can be the reasons for the findings obtained in this study. 
The other reason for the obtaining findings in this research can be that the online instruction allows the students to learn at a place and a time that is congruent with their learning needs. Consequently, the speaking anxiety of the students can be reduced. Online tools such as online English language learning websites [57], electronic dictionaries [58], chatting and e-mail messaging programs, online games, presentation software, and online media [59] may be effective learning tools that can facilitate learning by creating a more motivating and less anxiety-inducing environment in which learners focus on new words and their contextual use.

\section{Conclusions and Implications}

According to the outcomes obtained in this investigation, we can conclude that applying online education as a branch of CALL can bring about positive effects on Indonesian EFL students' vocabulary learning, speaking skill, and speaking anxiety. We can say that online instruction is a vital instrument that needs to be applied to supplement the EFL face-to-face instruction. It encompasses different tasks and resources that, if applied by the learners and controlled by the teachers, it can improve the students' language competencies. As the universe develops, we should use technology to synchronize ourselves with it. In addition, it can be concluded that diverse online instruments can have substantial impacts on the learning of the various aspects of language. Since all Indonesian schools and institutes are not equipped with the Internet, computers, and other online tools and the speed of the net is low in some places and some students do not access to smartphones, tablets, and computer, a combination of online learning and face-to-face instruction is offered in Indonesian contexts.

The findings of this research can help language learners to study anytime and anywhere. Conventionally, students have to attend a class at a certain time and in a fixed place. But, if these places have the Internet and computers, students can study and learn the same materials wherever they are. Students can even study outside of schools if their personal computers have a connection to the system or network in their schools. By using CALL, many funny games and communicative activities are provided for the students which can decrease the learning stress and anxiety.

The implications of this research can improve the communication between instructors and people. Contrary to the traditional second language classrooms, by online instruction, people can study more independently, leaving for the instructors more time to focus their attention on those elements of foreign language teaching that are still difficult or impossible by the computers, such as pronunciation, work on spoken dialogues, and teaching for essay writing and presentations [60]. Such individualized education can develop learners' active learning, enhance learning with comprehension, and permit learners to observe their progresses themselves.

The outcomes of this research can encourage English teachers to integrate technological-based methods into their classrooms in order to gain better educational achievements. By supplying lectures online, instructors can pave the way for the students to learn the lessons at their own speed. In addition, the outcomes of this research can persuade the material designers to integrate online instructions into EFL syllabuses.

There were some drawbacks in this research. One of them was the relatively small number of the subjects that was due to the problem of accessibility of students. Therefore, the representativeness of the participants must be regarded carefully. Further studies can include more participants to get richer findings. This research was conducted in a private language institute; other studies need to be done among high school and university students. This research applied preand posttests to gather its data; next, studies are strongly offered to use other tools such as interviews and attitude questionaries to collect more exact data about the effectiveness of CALL and online instruction. Future investigations can expand the treatment time and investigate the impacts of the CALL instruction on different skills and subskills of English language in different contexts.

\section{Data Availability}

The data that support the findings of this study are available from the corresponding author upon reasonable request.

\section{Conflicts of Interest}

The authors declare that they have no conflicts of interest.

\section{References}

[1] A. Hashemifardnia, S. Shafiee, F. Rahimi Esfahani, and M. Sepehri, "Effects of massive open online course (MOOC) on Iranian EFL learners' speaking complexity, accuracy, and fluency," Computer-Assisted Language Learning Electronic Journal (CALL-EJ), vol. 22, no. 1, pp. 56-79, 2021.

[2] N. S. Alahmadi, "The impact of computer-assisted language learning (CALL) on grammar acquisition by Saudi learners," International Journal of Language and Linguistics, vol. 6, no. 4, pp. 151-158, 2019.

[3] G. Davies, "ICT and modern foreign languages: learning opportunities and training needs," IJES, vol. 2, no. 1, pp. 1-18, 2002.

[4] H. Nachoua, "Computer-assisted language learning for improving students' listening skill," Procedia - Social and Behavioral Sciences, vol. 69, pp. 1150-1159, 2012.

[5] A. T. Dina and S.-I. Ciornei, "The advantages and disadvantages of computer assisted language learning and teaching for foreign languages," Procedia - Social and Behavioral Sciences, vol. 76, pp. 248-252, 2013.

[6] K. W. Lee, "English teachers' barriers to the use of computerassisted language learning," Internet TESOL Journal, vol. 6, no. 12 , pp. 56-73, 2000.

[7] M. Ateyah Al-Hnifat, R. Rashid, and O. Al-Smadi, "Classroom practices to decrease speaking anxiety among Saudi EFL. students: a study from learners' perspective," Trends in Social Sciences (TSS), vol. 2, no. 1, pp. 15-27, 2020.

[8] M. Liu and J. Jackson, "An exploration of Chinese EFL learners' unwillingness to communicate and foreign language anxiety," The Modern Language Journal, vol. 92, no. 1, pp. 71-86, 2008. 
[9] C. D. Nguyen and F. Boers, "The effect of content retelling on vocabulary uptake from a TED talk," Tesol Quarterly, vol. 53, no. 1, pp. 5-29, 2019.

[10] E. Peters and S. Webb, "Incidental vocabulary acquisition through viewing L2 television and factors that affect learning," Studies in Second Language Acquisition, vol. 40, no. 3, pp. 551-577, 2018.

[11] F. Teng, "Vocabulary learning through videos: captions, advance-organizer strategy, and their combination," Computer Assisted Language Learning, vol. 4, pp. 1-33, 2020.

[12] I. Miralpeix and C. Muñoz, "Receptive vocabulary size and its relationship to EFL language skills," International Review of Applied Linguistics in Language Teaching, vol. 56, no. 1, pp. 1-24, 2018.

[13] F. Enayati and A. Pourhosein Gilakjani, "The impact of computer assisted language learning (CALL) on improving intermediate EFL Learnersâ€ vocabulary learning," International Journal of language Education, vol. 4, no. 1, pp. 96-112, 2020.

[14] R. Kitajima, "The effect of instructional conditions on students' vocabulary retention," Foreign Language Annals, vol. 34, no. 5, pp. 470-482, 2001.

[15] M. Prensky, Digital Game-Based Learning, McGraw-Hill, New York, NY, USA, 2000.

[16] S. Vahdat and M. Eidipour, "Adopting CALL to improve listening comprehension of Iranian junior high school students," Theory and Practice in Language Studies, vol. 6, no. 8, pp. 1609-1617, 2016.

[17] N. Bani Hani, "Benefits and barriers of computer assisted language learning and teaching in the Arab world: Jordan as a model," Theory and Practice in Language Studies, vol. 4, no. 8 , pp. 1609-1615, 2014.

[18] G. Bas, "Evaluation of DynED courses used in elementary schools from the views of teachers in Turkey," Journal of Language and Linguistic Studies, vol. 6, no. 1, pp. 14-39, 2010.

[19] S. Al-Kahtani and S. Al-Haider, "Factors affecting the use of CALL by EFL female faculty members in Saudi higher education: current status," The JALT CALL Journal, vol. 6, no. 3, pp. 153-170, 2010.

[20] M. Levy, Computer Assisted Language Learning: Context and Conceptualization, Clarendon Press, Oxford, UK, 1997.

[21] N. Bani Hani, Designing an English Computerized Instructional Program for Jordanian Sixth Grade Students and Measuring its Effect on Their Achievement, Unpublished Doctoral Dissertation, Yarmouk University, Irbid, Jordan, 2009.

[22] H. Dulay and M. Burt, Viewpoints on English as a Second Language, Regents, New York, NY, USA, 1977.

[23] S. Krashen, The Input Hypothesis, Longman, London, UK, 1985.

[24] R. C. Gardner and P. D. MacIntyre, "A student's contributions to second-language learning. Part II: affective variables," Language Teaching, vol. 26, no. 1, pp. 1-11, 1993.

[25] V. Ramamuruthy, "The effects of task-based approach on speaking anxiety among ESL low proficiency diploma students," Universal Journal of Educational Research, vol. 7, no. 6, pp. 1363-1375, 2019.

[26] E. K. Horwitz, M. B. Horwitz, and J. Cope, "Foreign language classroom anxiety," The Modern Language Journal, vol. 70, no. 2, pp. 125-132, 1986.

[27] Z. Dörnyei, The Psychology of the Language Learner: Individual Differences in Second Language Acquisition, Lawrence Erlbaum Associates Publishers, Mahwah, NJ, USA, 2005.
[28] D. J. Young, “Creating a low-anxiety classroom environment: what does language anxiety research suggest?" The Modern Language Journal, vol. 75, pp. 426-439, 1992.

[29] H. Soodmand Afshar and M. Rahimi, "Reflective thinking, emotional intelligence, and speaking ability of EFL learners: is there a relation?" Thinking Skills and Creativity, vol. 19, pp. 97-111, 2016.

[30] N. Ahmed, Z. H. Pathan, and F. S. Khan, "Exploring the causes of English language speaking anxiety among postgraduate students of university of Balochistan, Pakistan," International Journal of English Linguistics, vol. 7, no. 2, pp. 99-105, 2017.

[31] H. Khatoony and L. Rahmani, "Difficulties and weaknesses of speaking skill among Iranian EFL learners: a review article of speaking obstacles in applied linguistic students," International Journal of Language, Literature, Culture and History Studies, vol. 2, no. 2, pp. 59-69, 2020.

[32] A. Parmawati, "Using analytic teams' technique to improve students' speaking skill," Edulitics (Education, Literature, and Linguistics) Journal, vol. 3, no. 2, pp. 21-25, 2018.

[33] D. Sartika, "Teaching speaking using the information GAP technique," English Education Journal, vol. 7, no. 3, pp. 273-285, 2016.

[34] A. Asysyifa, A. Handayani, and S. Rizkiani, "Students' speaking anxiety in EFL classroom," Indonesian EFL Journal, vol. 2, no. 4, pp. 581-587, 2019.

[35] G. Ellis and B. Sinclair, Learning to Learn English Learner's Book: A Course in Learner Training, Cambridge University Press, Cambridge, UK, 1989.

[36] A. S. Hornby, S. Wehmeier, and M. Ashby, Niu Jin Xian Dai Gao Ji Yin Han Shuang Jie Ci Dian: Oxford Advanced Learner's English-Chinese Dictionary, Oxford University Press, Oxford, UK, 2005.

[37] N. Ghanbari, M. Shamsoddini, and A. Radmehr, "The effect of CALL on vocabulary learning and reading comprehension of Iranian EFL learners," IOSR Journal of Research \& Method in Education, vol. 5, no. 4, pp. 95-103, 2015.

[38] D. Nunan, Second Language Teaching and Learning, Heinle and Heinle Publishers, Boston, MA, USA, 1999.

[39] A. Tozcu and J. Coady, "Successful learning of frequent vocabulary through CALL also benefits reading comprehension and speed," Computer Assisted Language Learning, vol. 17, no. 5, pp. 473-495, 2004.

[40] J. ., C. Richards and W. ., A. Renandya, Methodology in Language Teaching, Cambridge University Press, Cambridge, UK, 2002.

[41] T. Cobb, "Breadth and depth of lexical acquisition with handson concordancing," Computer Assisted Language Learning, vol. 12, no. 4, pp. 345-360, 1999.

[42] M. H. Ko and J. Goranson, "Technology-assisted vocabulary learning and student learning outcomes: a case study," Multimedia- Assisted Language Learning, vol. 17, no. 1, pp. 11-33, 2014.

[43] I. S. P. Nation, Teaching Vocabulary: Strategies and Techniques, Heinle Cengage Learning, Boston, MA, USA, 2008, https://trove.nla.gov.au/version/4479\%209110 Accessed.

[44] S. Thornbury, "How words are learned?," in How to Teach Vocabulary, J. Harmer, Ed., pp. 13-31, Pearson Education, Malaysia, 2002.

[45] S. Pahlavanpoorfard and A. Soori, "The impact of using computer software on vocabulary learning of Iranian EFL university students," International Journal of Applied Linguistics and English Literature, vol. 3, no. 4, pp. 23-28, 2014. 
[46] S. S. Mousavi and A. Nemati, "A comparative study of the Iranian EFL learners' vocabulary learning through two different formats: paper and pencil vs. software," Journal of Studies in Learning and Teaching English, vol. 6, no. 1, pp. 113-131, 2017.

[47] A. Zarei and M. Asadi Amani, "The effect of online learning tools on L2 reading comprehension and vocabulary learning," Journal of Teaching Language Skills, vol. 37, no. 3, pp. 211-238, 2018.

[48] M. Mahmoudi, "The effect of online learning on grammatical accuracy among EFL upper-intermediate learners," Journal of Language Teaching and Research, vol. 11, no. 6, pp. 1011-1016, 2020.

[49] F. Çakmak, E. Namaziandost, and T. Kumar, "CALL-enhanced L2 vocabulary learning: using spaced exposure through CALL to enhance L2 vocabulary retention," Educational Research International, vol. 2021, pp. 1-8, Article ID 5848525, 2021.

[50] J. d. D. Martínez Agudo, "Which instructional programme (EFL or CLIL) results in better oral communicative competence? Updated empirical evidence from a monolingual context," Linguistics and Education, vol. 51, pp. 69-78, 2019.

[51] L. Ding, E. Er, and M. Orey, "An exploratory study of student engagement in gamified online discussions," Computers \& Education, vol. 120, pp. 213-226, 2018.

[52] L. Harasim, Learning Theory and Online Technologies, Routledge/Taylor and Francis, New York, NY, USA, 2012.

[53] Siemens, Connectivism: A Learning Theory for the Digital Age, Siemens, Munich, Germany, 2004, http://www.elearnspace. org/Articles/connectivism.htm Paper retrieved from.

[54] B. Gilbert, "Online learning revealing the benefits and challenges," International Journal of Educational Research, vol. 3, no. 5, pp. 29-38, 2015.

[55] E. G. Chaney, "Web-based instruction in a rural high school: a collaborative inquiry into its effectiveness and desirability," NASSP Bulletin, vol. 85, no. 628, pp. 20-35, 2010.

[56] Z.-g. Ge, "Exploring e-learners' perceptions of net-based peerreviewed English writing," International Journal of ComputerSupported Collaborative Learning, vol. 6, no. 1, pp. 75-91, 2011.

[57] W. V. Wu, L. L. Yen, and M. Marek, "Using online EFL interaction to increase confidence, motivation, and ability," Educational Technology \& Society, vol. 14, no. 3, pp. 118-129, 2011.

[58] A. Zarei and P. Mahmoodzadeh, "The effect of multimedia glosses on L2 reading comprehension and vocabulary production," Journal of English Language and Literature, vol. 1, no. 1, pp. 1-7, 2014.

[59] J. Wood, "Can software support children's vocabulary development?” Language, Learning and Technology, vol. 5, no. 1, pp. 166-201, 2001.

[60] A. F. AbuSeileek, "Computer-assisted language learning: merits and demerits," Language in India, vol. 12, no. 4, pp. 23-36, 2012. 